\title{
Alveolar proteinosis lung lavage using partial cardiopulmonary bypass
}

\author{
ALLAN P FREEDMAN, ANASTASIOS PELIAS, ROBERT F JOHNSTON, \\ INDER P GOEL, HADI I HAKKI, THEODORE OSLICK, JAMES P SHINNICK
}

From Division of Pulmonary Diseases and Department of Cardiothoracic Surgery, Hahnemann Medical College and Hospital, Philadelphia, Pennsylvania, USA

ABSTRACT An adult case of pulmonary alveolar proteinosis presented with an arterial oxygen tension of $27 \mathrm{mmHg}(3.6 \mathrm{kPa})$ while breathing air. Dangerous hypoxaemia during lung lavage was avoided by using partial cardiopulmonary bypass.

Pulmonary alveolar proteinosis (PAP) is a relatively uncommon disease of unknown aetiology in which the alveoli are filled with an amorphous proteinaceous material, rich in phospholipid similar to pulmonary surfactant. ${ }^{12}$ This alveolar filling can seriously compromise gas exchange. Although some cases are associated with only mild symptoms, in others cough, dyspnoea, and hypoxaemia can be disabling. Whole lung lavage with saline has been shown to result in substantial improvement in most patients. $^{3-6}$ However, lung lavage may cause transient worsening of hypoxaemia, making the procedure hazardous in those patients most needing lavage. ${ }^{7} 8$ This report describes a patient with such severe arterial oxygen desaturation from PAP that cardiopulmonary bypass was used to maintain adequate arterial oxygenation during lung lavage.

\section{Case report}

This 45-year-old black woman (ES) noted the onset of mild dyspnoea five years before admission to hospital. The dyspnoea became worse two and a half months before her first admission. She became dyspnoeic at rest and noted light-headedness and blurred vision during any exertion. She developed a cough which became productive of white sputum. She denied chills, fever, haemoptysis, rashes, or arthralgia. Weight loss of 70 pounds over one year was attributed to dieting. The initial admission was prompted by the onset of inspiratory left chest pain. The chest radiograph revealed a diffuse, bilateral

Address for reprint requests: Dr Allan $\mathbf{P}$ Freedman, Division of Pulmonary Diseases, Hahnemann Medical College and Hospital, 230 N Broad Street, Philadelphia, PA 19102, USA. reticulonodular pulmonary infiltration. Arterial oxygen tension while breathing air was $46 \mathrm{mmHg}$ $(6.0 \mathrm{kPa})$ at that time. Open biopsy of the lingula demonstrated changes consistent with alveolar proteinosis. The alveoli were filled with granular PAS-positive, alcian blue-negative material. There was moderate interstitial inflammation. A trial of corticosteroid therapy for one month did not result in improvement and she was then admitted to our hospital for bronchopulmonary lavage.

In the past, she had experienced three episodes of pneumonitis, the last occurring eight years earlier. She had smoked half a pack of cigarettes a day for 10 years. For 10 years, she had worked as an assembler doing soldering in an electronics plant. Five years before admission, she left Philadelphia and moved to southern New Jersey where she lived in a rural area and worked as a nurses' aide in an institution for handicapped children.

Physical examination showed her to be in moderate respiratory distress. Blood pressure was 120/80 $\mathrm{mmHg}$, pulse $100 / \mathrm{min}$, temperature $37 \cdot 1^{\circ} \mathrm{C}$, respiratory rate $34 / \mathrm{min}$ with mild use of accessory muscles. Neck vein distention, clubbing, and lymphadenopathy were absent. Crackles occurring late in inspiration were heard at both lung bases. The heart was not enlarged, and no murmurs were heard, but a soft fourth sound was present. The liver and spleen were not enlarged. There was no oedema. Routine laboratory examination was unremarkable except for elevation of the haemoglobin to $16.7 \mathrm{~g} / \mathrm{dl}$ and a reduction of the albumin to $33 \mathrm{~g} / \mathrm{l}$. Serum LDH was 466 units (normal 100-225). Antinuclear antibody was negative, but rheumatoid factor was positive in a titre of $1: 80$. Arterial pH was $7.44(36 \mathrm{nmol} / \mathrm{l}), \mathrm{PCO}_{2} 31 \mathrm{mmHg}$ $(4.13 \mathrm{kPa})$, and $\mathrm{Po}_{2} 27 \mathrm{mmHg}(3.60 \mathrm{kPa})$ breathing 
Table 1 Arterial oxygen pressure and percentage venous admixture on spontaneous and mechanical ventilation before, during, and after lung lavage

\begin{tabular}{|c|c|c|c|c|}
\hline & \multicolumn{3}{|c|}{ Arterial $\mathrm{Po}_{2}(\mathrm{mmHg})$} & \multirow{2}{*}{$\begin{array}{l}\% \text { Venous admixture } \\
\begin{array}{l}\text { Mechanical } \\
\text { ventilation } \\
100 \% \mathrm{O}_{2}\end{array}\end{array}$} \\
\hline & $\begin{array}{l}\text { Spontaneous } \\
\text { ventilation } \\
21 \% \mathrm{O}_{2}\end{array}$ & $\begin{array}{l}\text { Spontaneous } \\
\text { ventilation } \\
100 \% \mathrm{O}_{2}\end{array}$ & $\begin{array}{l}\text { Mechanical } \\
\text { ventilation } \\
100 \% \mathrm{O}_{2}\end{array}$ & \\
\hline $\begin{array}{l}\text { Before lavage } \\
\text { During lavage of left lung } \\
\text { (cardiopulmonary bypass) }\end{array}$ & 27 & 59 & $\begin{array}{r}126 \\
43\end{array}$ & $32 \%$ \\
\hline $\begin{array}{l}\text { One week after lavage of left lung } \\
\text { During lavage of right lung }\end{array}$ & 33 & & $\begin{array}{r}233 \\
83\end{array}$ & $25 \%$ \\
\hline Two weeks after lavage of right lung & 48 & & & \\
\hline
\end{tabular}

Conversion: $\mathrm{mmHg} \times 0.133=\mathrm{kPa}$.

Table 2 Results of pulmonary function tests

\begin{tabular}{|c|c|c|c|c|c|}
\hline & $F E V_{1}(l)$ & $F V C(l)$ & $F R C(l)$ & $T L C(l)$ & DLco $(\mathrm{ml} / \mathrm{min} / \mathrm{mmHg})$ \\
\hline Predicted & $2 \cdot 31$ & $3 \cdot 15$ & $2 \cdot 64$ & $4 \cdot 78$ & $15 \cdot 49$ \\
\hline \multirow{2}{*}{\multicolumn{5}{|c|}{ One week after lavage of }} & $5 \cdot 11$ \\
\hline & & & & & \\
\hline \multirow{2}{*}{$\begin{array}{l}\text { Two weeks after lavage of } \\
\text { right lung }\end{array}$} & $1 \cdot 24$ & 1.40 & $1 \cdot 14$ & $1 \cdot 85$ & $7 \cdot 02$ \\
\hline & 1.55 & $1 \cdot 76$ & $1 \cdot 34$ & $2 \cdot 41$ & $11 \cdot 52$ \\
\hline
\end{tabular}

room air (table 1). It was $59 \mathrm{mmHg}(7.86 \mathrm{kPa})$ breathing $100 \%$ oxygen, giving an alveolar-arterial oxygen gradient of $654 \mathrm{mmHg}(87.2 \mathrm{kPa})$ equivalent to a right-to-left shunt of $47 \%$ of the cardiac output. Pulmonary function tests were indicative of severe restrictivelung disease (table 2). Bronchoscopy revealed no endobronchial lesions and bronchial washings were negative for bacteria, mycobacteria, and fungi. The tuberculin test was negative and fungal antibodies were absent.

Because of the severity of the arterial hypoxaemia, bronchopulmonary lavage was performed while on partial cardiopulmonary bypass. A pulmonary artery catheter inserted at this time showed the pulmonary artery systolic pressure to be $41 \mathrm{mmHg}$, the mean pressure $17 \mathrm{mmHg}$, diastolic pressure 4 $\mathrm{mmHg}$, and the pulmonary capillary wedge pressure $5 \mathrm{mmHg}$. Cardiac output was $5 \cdot 26 \mathrm{l} / \mathrm{min}$ by thermodilution. A Robertshaw double-lumen tube was passed into the trachea under halothane anaesthesia. Mechanical ventilation of both lungs with $100 \%$ oxygen resulted in an arterial $\mathrm{Po}_{2}$ of $126 \mathrm{mmHg}$ $(16.8 \mathrm{kPa})$ indicating a right-to-left shunt equal to $32 \%$ of the cardiac output. Because of the anticipated worsening during the lavage, partial venoarterial cardiopulmonary bypass was performed after full heparinisation using a Bentley BOS 10-bubble oxygenator. The left femoral artery was cannulated using a size 20 arterial cannula and the left common femoral vein was cannulated using a size 32 cannula. The venous cannula was advanced to the inferior vena cava for optimal drainage. A bypass flow of $2 \cdot 6$ $1 /$ min (half of the cardiac output) was used. The left lung was then lavaged with 12.751 of normal saline ( 23 cycles with an average volume/cycle of $554 \mathrm{ml}$ ), a total of 11.91 being recovered. A protocol similar to that described by Rogers et al was used. ${ }^{8}$ The effluent was initially turbid and full of debris, but gradually cleared. The lowest $\mathrm{Po}_{2}$ of blood from the radial artery during the lavage was $43 \mathrm{mmHg}(5 \cdot 73$ $\mathrm{kPa}$ ) (at the end of a drainage phase) and the arterial $\mathrm{Po}_{2}$ on $100 \%$ was $339 \mathrm{mmHg}(45.2 \mathrm{kPa})$ after the lavage and cardiopulmonary bypass were terminated. Total bypass time was one and a half hours.

The right lung was lavaged seven days later without the aid of cardiopulmonary bypass, as arterial $\mathrm{Po}_{2}$ had risen to $33 \mathrm{mmHg}(4.4 \mathrm{kPa})$ on room air and 233 $\mathrm{mmHg}(29.7 \mathrm{kPa})$ during mechanical ventilation of both lungs with $100 \%$ oxygen (right to left shunt of $25 \%$ ). The lowest $\mathrm{Po}_{2}$ measured during the second lavage was $83 \mathrm{mmHg}(11 \cdot 1 \mathrm{kPa})$ at the end of a drainage phase, while ventilating the left lung with $100 \%$ oxygen. During the next five months, the arterial $\mathrm{Po}_{2}$ rose to $69 \mathrm{mmHg}(9.2 \mathrm{kPa})$ on room air and the pulmonary infiltrates slowly cleared. Subsequent recurrence necessitated a second bronchopulmonary lavage.

\section{Discussion}

During the course of whole lung lavage for treatment of PAP, one lung is entirely filled and emptied repeatedly with a normal saline solution. ${ }^{34}$ The lung 
being lavaged is isolated from its mate by means of a double-lumen endotracheal tube. Since this lung has no ventilation, blood passing through it is not oxygenated. This mixed venous blood is added to oxygenated blood returning from the ventilated lung, causing lowering of arterial oxygen content. The amount of venous admixture is increased as pulmonary capillary blood flow increases in the lavaged lung. ${ }^{6} 8$ The blood flow through the nonventilated, lavaged lung depends upon the relationship between pulmonary artery pressure and the airway pressure. When airway pressure exceeds pulmonary capillary pressure, the vessels collapse and blood flow ceases. If pulmonary capillary pressure exceeds airway pressure, blood flow will occur. Airway pressure in the lavaged lung varies greatly during the procedure. During drainage the pressure is atmospheric, while when the lung is filled with saline, the airway pressure depends upon the height of the saline reservoir above the lung-in this case $30 \mathrm{~cm}$ water above atmospheric. Blood flow occurs through the lavaged lung during drainage, but ceases as saline filling occurs and the airway pressure exceeds pulmonary capillary pressure.

If pulmonary oxygen transfer is sufficiently deranged before lavage, the arterial $\mathrm{PO}_{2}$ during lavage could fall transiently to a dangerously low level, causing tissue hypoxia. This could preclude use of this treatment in a patient needing it the most. Although most patients undergoing lavage are not severely hypoxaemic, ${ }^{5} 6$ Ramirez- $R^{3}$ has reported lavage of a patient with PAP whose arterial $\mathrm{PO}_{2}$ was $28 \mathrm{mmHg}(3.73 \mathrm{kPa})$ on room air and $124 \mathrm{mmHg}$ $(16.5 \mathrm{kPa})$ on $100 \%$ oxygen. In two other patients it was noted that arterial $\mathrm{PO}_{2}$ on $100 \%$ oxygen fell from $82 \mathrm{mmHg}(10.9 \mathrm{kPa})$ to $38 \mathrm{mmHg}(5.7 \mathrm{kPa})$ and from $71 \mathrm{mmHg}(9.46 \mathrm{kPa})$ to $40 \mathrm{mmHg}(5 \cdot 3 \mathrm{kPa})$ respectively during lavage. ${ }^{4} 9$

Seard et al 1011 reported simultaneous bilateral lung lavage with the aid of partial cardiopulmonary bypass in two children with PAP in whom tracheal size did not permit the use of a double-lumen tube. In these cases, one-third of the cardiac output was diverted through the oxygenator, resulting in an arterial $\mathrm{Po}_{2}$ of $25-30 \mathrm{mmHg}(3 \cdot 3-4 \cdot 0 \mathrm{kPa})$ during lavage, a level we would not consider adequate for an adult.

Cooper et al ${ }^{12} 13$ reported a critically ill 24-year-old woman with PAP in whom serial bilateral lung lavage was performed while on partial bypass. Her arterial $\mathrm{Po}_{2}$ before bypass was below $50 \mathrm{mmHg}(6 \cdot 7$ $\mathrm{kPa}$ ) while being mechanically ventilated with $90 \%$ oxygen and $10 \mathrm{~cm}$ PEEP. On partial bypass, her arterial $\mathrm{PO}_{2}$ fell to no lower than $77 \mathrm{mmHg}(10 \cdot 3$ $\mathrm{kPa}$ ) during lavage. Altose et al ${ }^{14}$ describe the use of partial bypass during the initial unilateral lavage of a 32-year-old man with PAP whose arterial $\mathrm{Po}_{2}$ was 65 $\mathrm{mmHg}(8.7 \mathrm{kPa})$ breathing $100 \%$ oxygen by mouthpiece and $125 \mathrm{mmHg}(16.7 \mathrm{kPa})$ when mechanically ventilated with $100 \%$ oxygen. His lowest arterial $\mathrm{Po}_{2}$ during lavage was $46 \mathrm{mmHg}(6 \cdot 1 \mathrm{kPa})$. Our patient is physiologically similar to this case.

Partial cardiopulmonary bypass was used during our patient's initial lung lavage because of her severe hypoxaemia and the degree of venous admixture on $100 \%$ oxygen. $\mathrm{By}$ its use, her arterial $\mathrm{Po}_{2}$ was maintained above $43 \mathrm{mmHg}(5 \cdot 7 \mathrm{kPa})$ even during cyclic drainage of the lavage fluid. This first lavage improved lung function to the point where lavage of the opposite lung was conducted seven days later without bypass.

We are grateful to Dr Irwin Gratz for supervising the anaesthetic management of this patient. We also wish to thank Dr Robert Datesman for referring the patient to us.

\section{References}

${ }^{1}$ Rosen SH, Castleman B, Liebow AA. Pulmonary alveolar proteinosis. N Engl J Med 1958;258:1123-42.

2 Davidson JM, MacLeod WM. Pulmonary alveolar proteinosis. Br J Dis Chest 1969;63:13-28.

${ }^{3}$ Ramirez-R J. Bronchopulmonary lavage. New techniques and cbservations. Dis Chest 1966;50:581-8.

${ }^{4}$ Ramirez-R J. Alveolar proteinosis. Importance of pulmonary lavage. Am Rev Respir Dis 1971;103:666-78.

${ }^{5}$ Selecky PA, Wasserman K, Benfield JR, Lippmann M. The clinical and physiological effect of whole-lung lavage in pulmonary alveolar proteinosis: a ten-year experience. Ann Thorac Surg 1977;24:451-61.

${ }^{6}$ Rogers RM, Levin DC, Gray BA, Moseley LW Jr. Physiologic effects of bronchopulmonary lavage in alveolar proteinosis. Am Rev Respir Dis 1978;118:255-64.

? Wasserman K, Blank N, Fletcher G. Lung lavage (alveolar washing) in alveolar proteinosis. Am J Med 1968;44: 611-7.

${ }^{8}$ Rogers RM, Szidon JP, Shelburne J et al. Hemodynamic response of the pulmonary circulation to bronchomonary lavage in man. $N$ Engl J Med 1972;286:1230-3.

${ }^{9}$ Ramirez-R J. Pulmonary alveolar proteinosis. Treatment by massive bronchopulmonary lavage. Arch Intern Med 1967;119:147-56.

${ }^{10}$ Seard C, Wasserman K, Benfield JR et al. Simultaneous bilateral lung lavage (alveolar washing) using partial cardiopulmonary bypass. Am Rev Respir Dis 1970;101: 877-84.

${ }^{11}$ Lippmann M, Mok MS, Wasserman K. Anesthetic management for children with alveolar proteinosis using extracorporeal circulation. Br J Anaesth 1977;49:173-7.

12 Cooper JD, Duffin J, Glynn MFX et al. Combination of membrane oxygenator support and pulmonary lavage for acute respiratory failure. $J$ Thorac Cardiovasc Surg $1976 ; 71: 304-8$.

${ }^{13}$ Cooper JD. Combination of pulmonary lavage and extracorporeal membrane oxygenation support. In: Zapol WM, Qvist J, eds. Artificial lungs for acute respiratory failure. New York: Academic Press, 1976: 455-64.

${ }^{14}$ Altose MD, Hicks RE, Edwards MW Jr. Extracorporeal membrane oxygenation during bronchopulmonary lavage. Arch Surg 1976;111:1148-53. 